\title{
Geographical Analysis of Sex Ratio among Tribal Population in Nashik District, Maharashtra.
}

\author{
Anilkumar R. Pathare ${ }^{1}$, Jyoti A. Pathare ${ }^{2}$ \\ ${ }^{\text {land } 2}$ Assistant professor, Department of Geography, HPT Arts and RYK Science College Nashik. University of \\ Pune, India. 422005.
}

\begin{abstract}
Sex ratio is important parameter for the study of demographic, socio-cultural and economic status of any region. In the present study, attempt has been made to analyse the changed phenomena of sex ratio in tribal population of Nashik district of Maharashtra state. The demographic parameter has been taken into account for the study of human resource development. Any part of the world, sex ratio has given an important place in the study of human resource development. The regions, where sex ratio is low, have posed an unpleasant problem of gender discrimination, resulting in the fall in the status of human resource.
\end{abstract}

Keywords: sex ratio, gender.

\section{Introduction:}

In the study of population characteristic, age-sex structure is one of the most important characteristics of population composition. Age-sex analysis is based on age and sex structure of population. The data of agesex is more noticeable of rural-urban population, marital status, literacy, occupation structure, fertility and mortality. Apart from purely demographic concerns, age-sex data structure requires for educational, health services, planning, technical, political and commercial purposes. Sex composition directly affects on proportion of marital status, supply of labour, fertility, and migration and indirectly affects the literacy, birth rate and death rate. Imbalance in sex ratio is harmful to social structure. If proportion of males in total population is higher than the females, age of marriage for females decrease and it affects the female's health. In India, numbers of females are less than males because of male dominating culture, status of women in society; social security, educational facilities and less participation in decision making are the barrier. Therefore study of sex composition becomes very significant for socio-economic planning. For this study data regarding sex have collected at district level for total and tribal population for the year 1991 and 2001. The data for study have been collected from District Census Handbook Nashik district for the year 1991 and 2001.

\section{Study Area:}

The Nashik district of Maharashtra state has been selected for the proposed work. The extent of the district lies in $19^{\circ} 35^{\prime} \mathrm{N}$ and $20^{\circ} 52^{\prime} \mathrm{N}$ latitude $73^{\circ} 16^{\prime} \mathrm{E}$ and $74^{\circ} 56^{\prime} \mathrm{E}$ longitude, with an area of 15,582 sq kms (6,015 sq. miles)and it rank third in state with $5.04 \%$ area. Nashik district has a population of 49, 93,796 as per the census of 2001. Nashik district is Rhomboidal in shape with the longer diagonal of about $170 \mathrm{~km}$. from south-west to north-east and an extreme breadth of about $120 \mathrm{~km}$. from north to south, Nashik district lies in the north-west part of the state. (fig.1.1) 


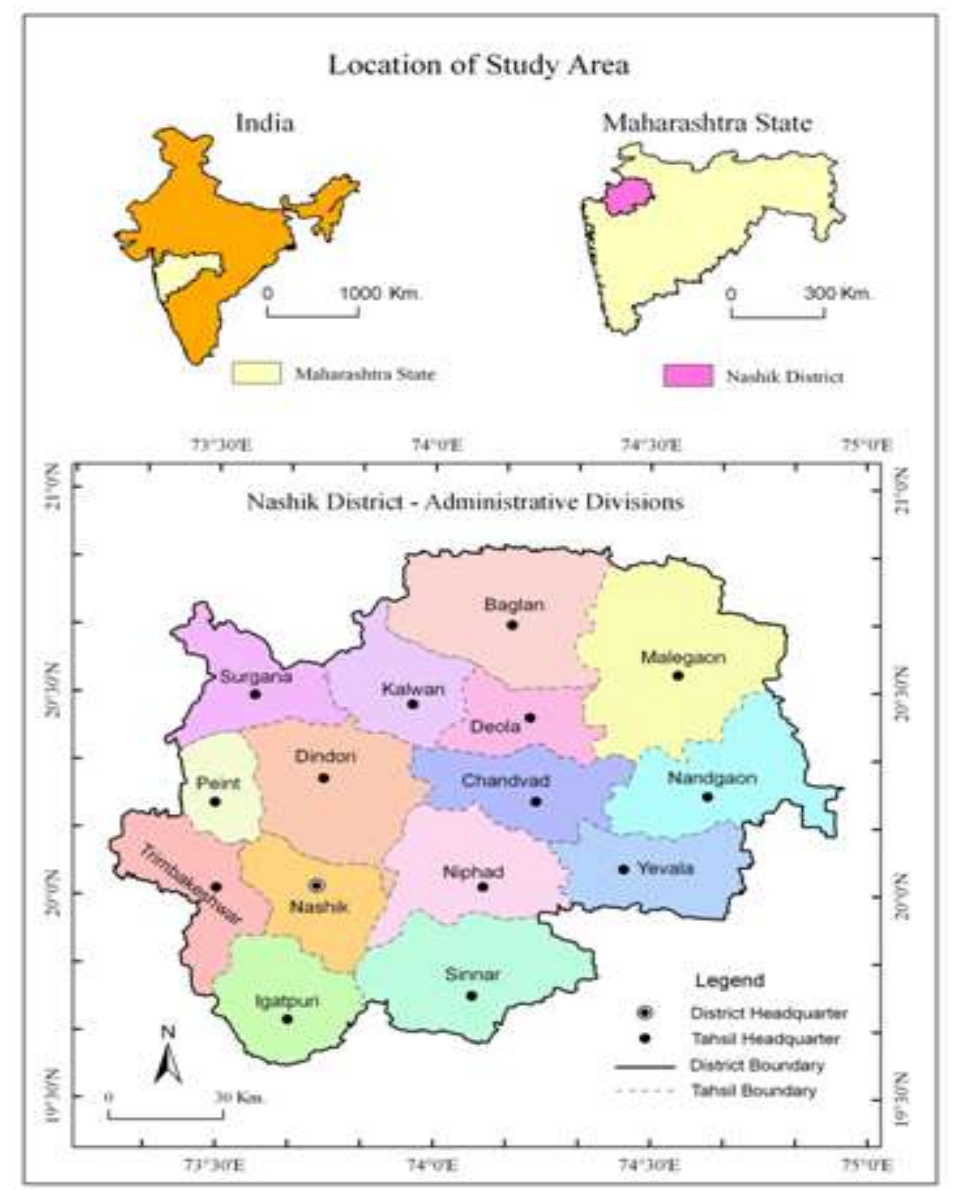

Fig.1.1

The fifteen tahasils of the district include Satana, Deola,(created on 26.06.1999) Malegaon, Surgana, Kalwan, Peint, Dindori, Trimbakeshwar, (created on 26.06.1999) Igatpuri, Sinnar, Nashik, Yevala, Niphad, Chandvad, Nandgaon (Fig ). Among these Malegaon is largest tahashil with $12 \%$ area and Peint is smallest tahasil with $3.63 \%$ area in the district.

The uneven development of district is mainly associated with the geographical and socio-economic disparities. Which may identify through the level of human resource development in the study region? The tahasil in the district can be classified to formulate the stratergy to resolve the problems of low level of social development. Gender equality is one of the important social parameter in human resource development. Thus such strategy may be useful to minimize the social economic disparities or problems.

\section{Aims and Objectives:}

Present study intends the following objectives-

1. To understand the level of sex ratio in Nashik district.

2. To compare the sex ratio of tribal population to total population.

3. To analyze the change in volume of sex ratio in the tahasils between 1991 and 2001.

\section{Sources of data:}

For present study data regarding sex have been collected at tahasil level for total and tribal population for the year 1991 and 2001. The data for study have been collected from District Census Handbook Nashik district for the year 1991 and 2001.

\section{Methodology:}

The proposed work aims at investigating the level of sex ratio of the study area, it will help to prepare action plan to achieve gender equality. No only this but also minimize the disparities in socio economic development within the study area. Finding out the level of significance tahasil wise correlation is used. 


\section{Sex ratio:}

The human population exhibits certain inhabitant characteristic in terms of sex composition (Joshi and Tiwari, 2011). The change in sex composition is largely reflecting the underlying socio-economic and cultural patterns of society. The ratio between male and female is called as sex ratio. In India, sex ratio defines the number of females per 1000 males in the population.

\section{Comparative sex ratio of the district and State}

Table: 1 . State and district sex ratio

\begin{tabular}{|l|l|l|l|l|l|l|l|l|l|}
\hline & \multicolumn{3}{|l|}{ Maharashtra } & \multicolumn{3}{l|}{ District } & \multicolumn{2}{l|}{ Difference } \\
\hline Years & Rural & Urban & Total & Rural & Urban & Total & Rural & Urban & Total \\
\hline 1901 & 1003 & 862 & 978 & 977 & 953 & 974 & -26 & 91 & -4 \\
\hline 1911 & 1000 & 796 & 966 & 985 & 973 & 984 & -15 & 177 & 18 \\
\hline 1921 & 994 & 776 & 950 & 973 & 895 & 960 & -21 & 119 & 10 \\
\hline 1931 & 987 & 790 & 947 & 969 & 928 & 963 & -18 & 138 & 16 \\
\hline 1941 & 989 & 810 & 949 & 965 & 894 & 953 & -24 & 84 & 4 \\
\hline 1951 & 1000 & 807 & 941 & 974 & 907 & 956 & -26 & 100 & 15 \\
\hline 1961 & 995 & 801 & 936 & 971 & 874 & 946 & -24 & 73 & 10 \\
\hline 1971 & 985 & 820 & 930 & 954 & 905 & 940 & -31 & 85 & 10 \\
\hline 1981 & 987 & 850 & 937 & 959 & 889 & 937 & -28 & 39 & 0 \\
\hline 1991 & 972 & 875 & 934 & 955 & 915 & 940 & -17 & 40 & 6 \\
\hline 2001 & 960 & 873 & 922 & 945 & 900 & 927 & -15 & 27 & 5 \\
\hline
\end{tabular}

Source: District Census Handbook, Nashik District, 2001.

Table- 1. exhibits total population sex ratio for Maharashtra and Nashik district form 1901 to 2001. The total sex ratio of Maharashtra in 1901 was 978 and it was 974 in study region. Only the year 1991, in which sex ratio of study region is less than the Maharashtra state. After this year it was continuously higher than the state.

\section{Tahasil wise Tribal population sex ratio}

Table: 2 Tribal population sex ratio 1991and 2001.

\begin{tabular}{|c|c|c|c|c|c|c|c|c|c|}
\hline \multirow{3}{*}{ Tahsils } & \multicolumn{9}{|c|}{ Tribal Population Sex ratio } \\
\hline & \multicolumn{3}{|c|}{ Rural } & \multicolumn{3}{|c|}{ Urban } & \multicolumn{3}{|c|}{ Total } \\
\hline & 1991 & 2001 & Change & 1991 & 2001 & Change & 1991 & 2001 & Change \\
\hline Nashik & 970 & 936 & -34 & 936 & 930 & -6 & 955 & 932 & -23 \\
\hline Peint & 993 & 998 & 5 & - & - & - & 993 & 998 & 5 \\
\hline Dindori & 978 & 971 & -7 & - & - & - & 978 & 971 & -7 \\
\hline Surgana & 993 & 998 & 5 & - & 887 & - & 993 & 995 & 2 \\
\hline Kalvan & 994 & 1000 & 6 & - & - & - & 994 & 1000 & 6 \\
\hline Baglan & 973 & 969 & -4 & 940 & 978 & 38 & 972 & 969 & -3 \\
\hline Malegaon & 964 & 968 & 4 & 1023 & 985 & -38 & 971 & 970 & -1 \\
\hline Chandwad & 976 & 983 & 7 & 982 & - & N.A. & 977 & 983 & 6 \\
\hline Nandgaon & 968 & 953 & -15 & 938 & 931 & -7 & 964 & 950 & -14 \\
\hline Yeola & 961 & 984 & 23 & 954 & 934 & -20 & 960 & 981 & 21 \\
\hline Niphad & 969 & 975 & 6 & 965 & 999 & 34 & 968 & 976 & 8 \\
\hline Sinnar & 974 & 976 & 2 & 948 & 969 & 21 & 973 & 976 & 3 \\
\hline Igatpuri & 994 & 979 & -15 & 819 & 959 & 140 & 989 & 978 & -11 \\
\hline Trimbakeshwar & - & 991 & N.A. & - & 951 & N.A. & N.A. & 990 & N.A. \\
\hline Devala & - & 960 & N.A. & - & - & N.A. & N.A. & 960 & N.A. \\
\hline District Total & 982 & 980 & -2 & 944 & 939 & -5 & 979 & 976 & -3 \\
\hline
\end{tabular}

Source : District Census Handbook, Nashik District, (1991 and 2001).

Note : Figures shows no females per thousand males.

Table-2 shows the tribal population sex ratio in 1991 and 2001. According to Census 1991, average tribal population sex ratio in study region was 979 females. Peint and Surgana tahasils accounts 989 females and ranks first in the study region. The high sex ratio of more than 975 females has been observed in Peint, Surgana, 
Dindori, Kalvan, Chandwad, and Igatpuri towards west parts in study region. The sex ratio in between 950 to 975 was found in remaining all tahasils. Nashik tahasil exhibits lowest sex ratio (955) in study region. There was no single tahasil which had tribal sex ratio less than 950. It is observed that high sex ratio is in west part and moderate sex ratio in central-east parts in study region. This has attributed to out migration tribal people for employment and education. In 2001 tribal sex ratio accounting 976 in study region. The lowest sex ratio was observed in Nashik tahasil accounting 932 due to urbanization, industrialization of immigration of males in city for education and employment. The highest tribal sex ratio was observed in Kalvan (1000) followed by Peint (998), Surgana (995), Trimbakeshwar (990), Chandwad (983), Yeola (981), Igatpuri (978). Niphad (976) and sinner (976). The sex ratio in between 950 to 975 was found in malegoan (970), Baglan (969),Devala (960) and Nandgoan (950). Nashik tahasil exhibits lowest tribal sex ratio (932) in study region. It also observed that high tribal sex ratio is in west part and moderate sex ratio in central-east parts in study region. Tribal sex ratio in study area in 1991 was 979 females per 1000 male and It was 976 females per 1000 male in 2001. Sex ratio has declined for tribal population by (-3) during this decade in the study area. Tahasils namely Peint, Surgana, Kalvan, Chandwad, Yevala, Niphad, and sinner have increased tribal sex ratio during the decade.

The rural tribal sex ratio of study region in 1991 was 982 . The highest tribal rural sex ratio was recorded by Kalvan and Igatpuri (994) followed by Peint and Surgana (993). The lowest sex ratio was observed at Malegoan (964). In 2001 study region recorded 980 females per 1000 males in tribal population. Highest tribal rural sex ratio was recorded by Kalvan tahasil (1000) followed by Peint (998), Surgana (998) and Trimbakeshwar (991). The lowest sex ratio was observed at Nashik tahasil (936). Decadal change of tribal rural sex ratio in study region shows that there is decrease in sex ratio by (-2). Tahasils in study region namely Nashik (-34), Dindori (-7), Baglan (-4), Nandgaon (-15), Igatpuri (-15) show a decrease in sex ratio. Remaining tahasils show an increase in tribal rural sex ratio during the decade.

Urban tribal sex ratio in study region was 944 and decreased by (-5) and fall up to 939 in 2001. Malegoan was recorded highest tribal urban sex ratio 1023 and Igatpuri reported lowest urban sex ratio 819 in 1991 . In 2001 Niphad tahasil was recorded highest (999) and Surgana reported lowest (887) tribal urban sex ratio. Baglan, Niphad, Sinner and Igatpuri tahasils increased their tribal urban sex ratio during the decade by (38), (34), (21), and (140), successively. The significant increase in tribal urban sex ratio was observed in Igatpuri tahasil (140). Tribal urban sex ratio is less as compared to tribal rural sex ratio due to immigration in urban centres. But urban sex ratio was high than the rural sex ratio in Baglan, Malegoan and Niphad in 2001.

Remarkable thing is noted that the sex ratio of tribal and total population have been declining, the decline of the total population sex ratio is at high level (-13) and tribal sex ratio at low level (-3). It also observed that tribal population sex ratio was always higher in rural, urban and total terms than the total population of the study area. Another important thing is that urban centres adversely affect the sex ratio.

\section{Conclusions:}

1. Sex ratio was found to be decline fast among total population than the tribal population in 1991-2011.

2. Tribal population Sex ratio (urban and rural) is higher than the total population.

3. Though sex ratio is high among the tribal population in the study region, level of socio economic development is less in tribal concentrated areas.

4. Hence it is necessary to study other parameters that influence the socio-cultural and economic status of the study area.

\section{References:}

[1] Agarwal P.C.and Khan Z.T.(1988), “ Spatial Analysis of the level of regional development in Madhya Pradesh”, Modern Geographical trends, Ed.By P. Pandey, p.p.315.

[2] Agrahari, K.C., Singh, V.K., Chandana, V. (2008) : "Demographic study and Sustainable Development of Sonbhadra District, U. P ", Uttar Bharat Bhoogol Patrika, Gorakhpur, Vol. 38, No.12, Pp. 107-109

[3] Bhasin V. (2004) : Sexual Illness and Underutilization of Biomedicine among Tribal Women of Rajasthan. Anthropologist, 6(1): 112.

[4] Bhat, A. R. (2005) : "Human Resources and Socio-economic Development in Kashmir Valley-A Geographical Interpretation", Dilpreet Publishing House, New Delhi.

[5] Bhende, A., Kanitkar, T. (1978): "Principal of Population Studies", Himalaya Publishing House, Mumbai.

[6] Census of India 2001 (2001): "Sex-composition of The Population”, Chapter 6, Census of India 2001, Series 1, India, Paper 1 of 2001

[7] Chaudhari, B. (1982) : Tribal Development in India, Problem and Prospects,

[8] Jain, N. (1998) : Tribals in Maharashtra State: A Report. In: Vidyut Joshi (Ed.): Tribal Situation in India, Issues in Development., Rawat Publications, Jaipur, pp. 91-104. Inter India Publication.

[9] Joshi, A. and Tiwari, N. (2011) : "Sex Ratio in India-Embarrassing to be Honest", Current Science, Vol. 101, No. 8, Pp. 1006-1008.

[10] Musmade A., More J., Saptarshi P (2011) : A Geographical analysis of sex ratio in Rahuri tahasil of Ahmednagar district., paper Vol.XXVII (2).

[11] Pendharkar, S. (1990) : "Special pattern of sex ratio in south Kokan", Contributors to Indian Geography, Heritage publishers, New Delhi.

[12] Raju, S. (2011) : “Child Sex Ratio in India-The Emerging Pattern”, Yojana, New Delhi, Vol. 55, Pp. 21-27. 